OPEN ACCESS

Edited by:

Douglas Marc Silverstein, United States Food and Drug Administration, United States

Reviewed by:

Kimberly Jean Reidy,

Montefiore Medical Center,

United States

Aftab S. Chishti,

University of Kentucky, United States

*Correspondence:

Hassib Chehade

hassib.chehade@chuv.ch

Specialty section:

This article was submitted to

Pediatric Nephrology,

a section of the journa

Frontiers in Pediatrics

Received: 24 July 2018 Accepted: 30 November 2018 Published: 18 December 2018

Citation:

Libudzic-Nowak AM, Cachat F,

Pascual M and Chehade H (2018) Darbepoetin Alfa in Young Infants With

Renal Failure: Single Center Experience, a Case Series and Review of the Literature. Front. Pediatr. 6:398. doi: 10.3389/fped.2018.00398

\section{Darbepoetin Alfa in Young Infants With Renal Failure: Single Center Experience, a Case Series and Review of the Literature}

\author{
Anna Maria Libudzic-Nowak ${ }^{1,2}$, Francois Cachat ${ }^{1}$, Manuel Pascual ${ }^{2}$ and Hassib Chehade ${ }^{1 *}$ \\ ${ }^{1}$ Pediatric Nephrology Unit, Lausanne University Hospital (CHUV), Lausanne, Switzerland, ${ }^{2}$ Transplantation Center, Lausanne \\ University Hospital (CHUV), Lausanne, Switzerland
}

Background: Anemia treatment in infants with advanced or chronic kidney disease (CKD) represents an important challenge to nephrologists. The use of darbepoetin alfa, a novel erythropoiesis stimulating agent, has largely replaced recombinant human erythropoietin in older children and in adults with CKD. However, studies reporting the use of darbepoetin alfa in infants below 1 year of age are rare.

Case presentation: We report the data of three infants with advanced stage kidney failure, aged 1, 4, and 7 months, who were treated with darbepoetin alfa and followed for 18-41 months. Hemoglobin levels increased in all three patients, reaching the target levels of 10.7-12 g/dl by 11,19 , and 22 weeks respectively, without any documented adverse effects. Patients younger than 1 year of age required a larger darbepoetin alfa dosage (ranged from 1.2 to $2.9 \mu \mathrm{g} / \mathrm{kg}$ per month) as compared to older children. A review of the literature found only three studies using darbepoetin alfa successfully in such young infants, with similar dosage and clinical success.

Conclusion: In these three patients with advanced kidney disease, darbepoetin alfa was effective in correcting anemia with no observed side effects. It reinforces its potential use in very young patients with advanced CKD.

Keywords: anemia, darbepoetin alfa, chronic kidney disease, infant, pediatric

\section{BACKGROUND}

Anemia in children with chronic kidney disease (CKD) is recognized as an important comorbidity factor and is associated with growth retardation and cognitive dysfunction (1), as well as increased cardiovascular risk $(2,3)$, and accelerated CKD progression (4). Recent studies in the pediatric CKD population have indicated an increased risk of hospitalization and death in children with anemia, as compared to children with appropriate hemoglobin levels $(5,6)$.

The National Kidney Foundation Kidney Disease Outcomes Quality Initiative (NKF KDOQI) guidelines recommend, in dialysed and non-dialysed children with CKD, a target hemoglobin level between 11 and $12 \mathrm{~g} / \mathrm{dl}$ (7). According to the Kidney Disease Improving General Outcome (KDIGO) guidelines, anemia in children between 1 and 2 years of age with CKD, is defined as hemoglobin levels below $10.7 \mathrm{~g} / \mathrm{dl}$ in boys and $10.8 \mathrm{~g} / \mathrm{dl}$ in girls (8). It has been demonstrated that the use of erythropoiesis stimulating agents (ESA) for anemia in children with CKD decreases morbidity and mortality, reduces the need for blood transfusions, and improves growth (9). 
Darbepoetin alfa (Aranesp ${ }^{\circledR}$ ) is a hyperglycosylated epoetin analog with a similar mechanism of action as recombinant human erythropoietin (rHuEpo) and methoxy-polyethylene glycol-epoetin beta $\left(\right.$ Mircera $\left.^{\circledR}\right)$. The administration of darbepoetin alfa can be less frequent (weekly to monthly) than that of rHuEpo, for which the recommended administration frequency is $2-3$ times per week (10). This latter dosing schedule can be cumbersome in infants and may lead to difficulties in obtaining target hemoglobin levels.

During the past 10 years, darbepoetin alfa has largely replaced rHuEpo in older children and in adults with CKD. However, data regarding the safety and efficacy of darbepoetin alfa in infants $<1$ year of age with CKD are rare (11-13). We hereby describe the successful use of darbepoetin alfa in three infants under the age of 8 months with advanced CKD and we performed a short nonsystematic literature review regarding the use of darbepoetin alfa in infants $<1$ year of age with CKD.

\section{PATIENTS AND METHODS}

\section{Case Study}

The clinical course and laboratory data of three male infants with advanced chronic kidney disease, aged 1, 4, and 7 months at the beginning of therapy, were retrospectively reviewed. Patients were followed for a minimum of 18 months (patient 3) and a maximum of 41 months (patient 1 ).

The baseline hemoglobin, iron, and ferritin levels were recorded (Table 1). Hemoglobin levels were measured before each darbepoetin alfa injection. Darbepoetin was first administered intravenously then subcutaneously in all patients. Target hemoglobin levels were established at 10.7-12 $\mathrm{g} / \mathrm{dl}$. All three patients were on oral iron supplement therapy [5 $\mathrm{mg} / \mathrm{kg}$ of iron (III)-hydroxide polymaltose]. Adjustments of darbepoetin alfa dosage of $\sim 25 \%$ were made if hemoglobin measurement remained below the target levels. Potential adverse effects (hypertension, seizures, local pain or inflammation, thrombocytosis) and unexpected reactions were all recorded during the follow-up.

\section{Literature Review}

We searched the PubMed and Cochrane Library from the date of their inception to September, 12, 2018, to identify articles on darbepoetin alfa use in children aged $<1$ year using the keywords “darbepoetin" AND ("infant" OR “newborn”). We retrieved 33 articles, limited to humans and published in the English language. After reading the full text, three studies were included in our review. From the literature and appropriately selected papers, we also compared the pharmacology and pharmacokinetics of darbepoetin alpha in very young children receiving the drug for indications other than CKD.

Abbreviations: CKD, chronic kidney disease; ESA, erythropoiesis stimulating agents; eGFR, estimated glomerular filtration rate; NKF KDOQI, National Kidney Foundation Kidney Disease Outcomes Quality Initiative; rHuEpo, recombinant human erythropoietin.

\section{RESULTS}

Patient 1 was a 7-month-old boy with CKD due to obstructive uropathy, with an estimated glomerular filtration rate (eGFR) of $30 \mathrm{ml} / \mathrm{min} \times 1.73 \mathrm{~m}^{2}$. His anemia had been previously treated with epoetin beta (Recormon ${ }^{\circledR}$ ) at the doses of 160 UI/kg twice a week. Despite epoetin alfa treatment associated with oral iron (4-6 mg/kg daily) and folic acid $(1-2.5 \mathrm{mg} / \mathrm{kg}$ weekly) supplementations, adequate hemoglobin levels were not achieved. A switch to darbepoetin alfa at a mean dosage of 0.6 $\mu \mathrm{g} / \mathrm{kg}$ twice per month allowed reaching hemoglobin target levels by week 11 (Figure 1A, Table 1). Treatment was interrupted for 2 months secondary to hemoglobin values above the target levels. It was then reintroduced at a slightly lower dose of $0.54 \mu \mathrm{g} / \mathrm{kg}$ twice per month, and then at a dose of $0.94 \mu \mathrm{g} / \mathrm{kg}$ monthly, with a favorable response (Tables 1, 2). After 41 months of follow-up, the hemoglobin level was $12 \mathrm{~g} / \mathrm{dl}$ (Table 2). No adverse reaction was recorded during the treatment period.

Patient 2 was a 1-month-old newborn with severe renal failure due to obstructive uropathy (eGFR $<10 \mathrm{ml} / \mathrm{min} \times 1.73 \mathrm{~m}^{2}$ ). He was temporarily dialysed for 2 weeks during the neonatal period because of fluid overload and severe hyponatremia. Treatment with darbepoetin alfa was initially started at a dose of 0.8 $\mu \mathrm{g} / \mathrm{kg}$ subcutaneously twice per month, and then increased to a mean dose of $1 \mu \mathrm{g} / \mathrm{kg}$, given at a mean interval of 2.8 weeks (Figure 1B, Table 2) together with oral iron supplementation (5 $\mathrm{mg} / \mathrm{kg} / \mathrm{d})$. This allowed reaching his hemoglobin target level at week 19. After 19 months of follow-up the hemoglobin level was $11.8 \mathrm{~g} / \mathrm{dl}$. There were no adverse effect recorded during therapy.

Patient 3 was a 4-month-old infant with advanced renal failure (eGFR $<20 \mathrm{ml} / \mathrm{min} \times 1.73 \mathrm{~m}^{2}$ ), secondary to obstructive uropathy. Darbepoetin alfa treatment was started at a dose of 1 $\mu \mathrm{g} / \mathrm{kg}$ twice a month, associated with oral iron supplementation $(5 \mathrm{mg} / \mathrm{kg} / \mathrm{d})$. Target hemoglobin level was reached at week 22, with a mean dose of darbepoetin alfa of $1.1 \mu \mathrm{g} / \mathrm{kg}$ every other week (Figure 1C, Table 2). After 18 months of follow-up, the hemoglobin level was stable at $11 \mathrm{~g} / \mathrm{dl}$ (Table 1). No side-effects were recorded during follow-up. The iron stores evaluated at the beginning of the treatment were low for all of infants. Oral iron substitution allowed correction of iron deficit in all patients.

\section{DISCUSSION}

We report the cases of three infants aged 1-7 months with anemia and advanced CKD who were successfully treated with darbepoetin alfa. Although darbepoetin alfa has been effectively used in children with CKD above the age of 1 year (1416), studies reporting the use of this treatment in a younger population remain sparse. Durkan et al. (12) were the first to demonstrate the efficacy of darbepoetin alfa in a study including six infants with anemia due to CKD, aged 0.9-7.9 months with a mean weight of $4 \mathrm{~kg}$ and creatinine levels between 126 and 340 $\mu \mathrm{mol} / \mathrm{l}$. This retrospective study revealed an optimal response to treatment with darbepoetin alfa at a relatively small dose $(0.25 \mu \mathrm{g} / \mathrm{kg} /$ week $)$ in three patients, but surprisingly no effect on hemoglobin level in the three other infants with medical complications, and this despite adjusting dosage up to 1.1 
TABLE 1 | Characteristics of patients at baseline and at the last control.

\begin{tabular}{|c|c|c|c|c|c|c|c|c|c|c|}
\hline \multirow[b]{2}{*}{ Patient } & \multicolumn{5}{|c|}{ Baseline } & \multicolumn{5}{|c|}{ Last control } \\
\hline & $\begin{array}{c}\text { Age } \\
\text { (months) }\end{array}$ & $\begin{array}{c}\text { Hemoglobin } \\
(\mathrm{g} / \mathrm{l})\end{array}$ & $\begin{array}{c}\text { Creatinine } \\
(\mu \mathrm{mol} / \mathrm{l})\end{array}$ & $\begin{array}{c}\text { Iron } \\
(\mu \mathrm{mol} / \mathrm{l})\end{array}$ & $\begin{array}{c}\text { Ferritin } \\
(\mu \mathrm{g} / \mathrm{l})\end{array}$ & $\begin{array}{c}\text { Age } \\
\text { (months) }\end{array}$ & $\begin{array}{l}\text { Hemoglobin } \\
\text { (g/dl) }\end{array}$ & $\begin{array}{c}\text { Creatinine } \\
\text { ( } \mu \mathrm{mol} / \mathrm{l})\end{array}$ & $\begin{array}{c}\text { Iron } \\
(\mu \mathrm{mol} / \mathrm{l})\end{array}$ & $\begin{array}{c}\text { Ferritin } \\
(\mu \mathrm{g} / \mathrm{l})\end{array}$ \\
\hline 1 & 7 & 9.3 & 135 & 11.4 & 27 & 48 & 12.1 & 142 & 15.9 & 146 \\
\hline 2 & 1 & 10.7 & 249 & 14.7 & 96 & 20 & 11.8 & 445 & 15.6 & 109 \\
\hline 3 & 4 & 7.7 & 235 & 15.2 & 485 & 22 & 11.0 & 150 & N/A & $\mathrm{N} / \mathrm{A}$ \\
\hline
\end{tabular}
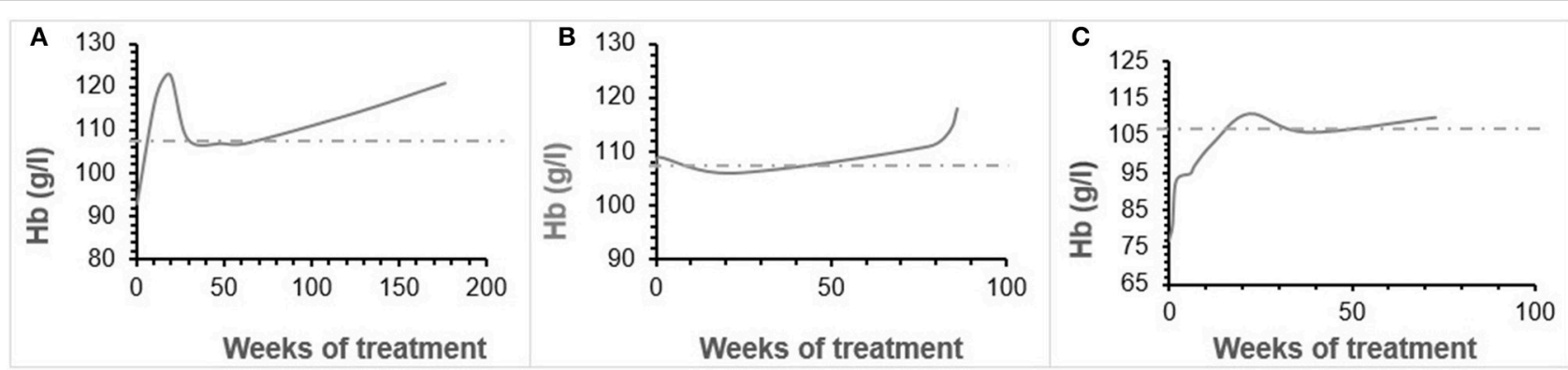

FIGURE 1 | (A-C) Hemoglobin evolution in patient 1, 2, 3.

TABLE 2 | Darbepoetin alfa doses and intervals.

\begin{tabular}{|c|c|c|c|c|}
\hline \multirow[b]{2}{*}{ Patient } & \multicolumn{2}{|c|}{ Before achieving $\mathrm{Hb}$ target } & \multicolumn{2}{|c|}{ At the last control } \\
\hline & $\begin{array}{c}\text { Dose of } \\
\text { darbepoetin } \\
(\mu \mathrm{g} / \mathrm{kg}) \\
\text { Mean }(S D) \\
\text { Range }\end{array}$ & $\begin{array}{c}\text { Interval between } \\
\text { doses (weeks) } \\
\text { Mean (SD) } \\
\text { Range }\end{array}$ & $\begin{array}{c}\text { Dose of } \\
\text { darbepoetin } \\
(\mu \mathrm{g} / \mathrm{kg})\end{array}$ & $\begin{array}{c}\text { Interval } \\
\text { between doses } \\
\text { (weeks) }\end{array}$ \\
\hline 1 & $\begin{array}{l}0.6(0.02) \\
0.58-0.62\end{array}$ & $\begin{array}{c}2.2(0.44) \\
2-3\end{array}$ & 0.94 & 4 \\
\hline 2 & $\begin{array}{c}1.02(0.19) \\
0.75-1.2\end{array}$ & $\begin{array}{c}2.83(0.98) \\
2-4\end{array}$ & 1.0 & 2 \\
\hline 3 & $\begin{array}{r}1.1(0.16) \\
1.0-1.45\end{array}$ & $\begin{array}{c}2(0) \\
2\end{array}$ & 1.0 & 2 \\
\hline
\end{tabular}

$\mu \mathrm{g} / \mathrm{kg} /$ week. All infants were treated for a 20 -week period at 1 to 4 week intervals between doses. In this study the hemoglobin target was fixed at 10-11 g/dl based on NKF K/DOQI guidelines (2000) and the recommendations of Royal College of Physicians and the London Renal Association, which is lower than the hemoglobin target in our study. The authors concluded that darbepoetin alfa can be successfully administered in infants, but the dosage needs to be tailored to each individual with varying response, potentially depending on general medical condition.

Rijk et al. (11) reported, in a retrospective multicenter study, 19 children on nightly intermittent peritoneal dialysis, with a mean age of 6.8 years (range $0-17$ years). All children received darbepoetin alfa intraperitoneally for a median period of 13 months. The initially administered dose of darbepoetin alfa was $0.45 \mu \mathrm{g} / \mathrm{kg} /$ week, adjusted monthly, and reaching a dosage of $0.63 \mu \mathrm{g} / \mathrm{kg} /$ week to allow keeping stable hemoglobin levels. The following adverse effects were reported: headache, hypertension, and peritonitis (15 episodes). The authors concluded that intraperitoneal treatment with darbepoetin alfa is an effective alternative to $\mathrm{rHuEpo}$ treatment, with less frequent administration in children with CKD. Unfortunately, the exact age for each individual was not described, and the exact number of patients $<1$ year of age and their precise clinical outcome are not available.

Recently, Schaefer et al. (13), in a multicenter phase IV prospective study, reported that darbepoetin alfa to be very effective in treating anemia. The study included 13 infants $<1$ year of age with CKD. Twelve out of 13 patients were on darbepoetin treatment at the inclusion. After enrolment, they received darbepoetin alfa at a mean dosage of 1.7$3.2 \mu \mathrm{g} / \mathrm{kg} /$ month subcutaneously or intravenously, which was higher than doses administrated to older children (1.2-2.7 $\mu \mathrm{g} / \mathrm{kg} / \mathrm{month}$ for those aged 1-17 years). Darbepoetin alfa dosage was also higher if administrated intravenously or in dialysed patients. A significant number of adverse events (10 cases) were reported in this age subgroup (hypertension, diarrhea and gastroenteritis, convulsion, pyrexia, catheter-site infection, device-related infection, and peritonitis). The mean hemoglobin levels rose between 3 and 6 months after the beginning of the treatment and remained stable during the follow-up of maximum 2 years (after 15 months of follow-up data were available for 6 patients younger than 1 year at the enrolment). These results confirm the efficacy of darbepoetin alfa in correcting anemia in infants $<1$ year of age with CKD. Table 3 summarizes the 3 above-mentioned studies.

Darbepoetin alfa has been used in young infants for indications other than $\mathrm{CKD}$. In a randomized placebo-controlled study, Ohls et al. (17) showed that darbepoetin alfa was successful in minimizing transfusion needs and maintaining red cell mass in 
TABLE 3 | Summary of studies reporting the use of darbepoetin alfa in infants $<1$ year of age.

\begin{tabular}{|c|c|c|c|c|c|c|c|c|}
\hline $\begin{array}{l}\text { Authors/ } \\
\text { Year of the } \\
\text { study }\end{array}$ & $\begin{array}{l}\text { Type of the } \\
\text { study }\end{array}$ & $\begin{array}{l}\text { No of } \\
\text { patients } \\
<1 \text { year of } \\
\text { age }\end{array}$ & $\begin{array}{l}\text { Treatment } \\
\text { indication }\end{array}$ & $\begin{array}{l}\text { Doses } \\
(\mu \mathrm{g} / \mathrm{kg} \\
\text { /month) }\end{array}$ & $\begin{array}{l}\text { Administration } \\
\text { frequency }\end{array}$ & $\begin{array}{l}\text { Treatment } \\
\text { duration/ } \\
\text { Follow-up }\end{array}$ & $\begin{array}{c}\text { Target Hb } \\
(g / d l)\end{array}$ & $\begin{array}{l}\text { Adverse effects } \\
\text { (number of patients) }\end{array}$ \\
\hline $\begin{array}{l}\text { Durkan et al. } \\
\text { (12) }\end{array}$ & $\begin{array}{l}\text { Retrospective } \\
\text { case-series }\end{array}$ & 6 & $\begin{array}{l}\text { CKD-induced } \\
\text { anemia }\end{array}$ & $1.0-4.8$ & 1-4 weeks & 20 weeks & $10-11$ & Injection site pain (6) \\
\hline Rijk et al. (11) & $\begin{array}{l}\text { Retrospective } \\
\text { two-center } \\
\text { single-arm }\end{array}$ & $\begin{array}{l}\text { Not defined } \\
\text { (19 patients } \\
\text { of age range } \\
0-17 \text { years) }\end{array}$ & $\begin{array}{l}\text { CKD-induced } \\
\text { anemia }\end{array}$ & $1.8-6.88$ & 1-2 weeks & $\begin{array}{l}\text { Range 2-40 } \\
\text { months } \\
\text { (median } 13.4 \\
\text { months) }\end{array}$ & $10.9-12.8$ & $\begin{array}{l}\text { Hypertension (3) } \\
\text { Headache (1) } \\
\text { Peritonitis (15) }\end{array}$ \\
\hline $\begin{array}{l}\text { Schaefer } \\
\text { et al. (13) }\end{array}$ & $\begin{array}{l}\text { Prospective } \\
\text { multicenter } \\
\text { observational }\end{array}$ & 13 & $\begin{array}{l}\text { CKD- induced } \\
\text { anemia }\end{array}$ & $1.7-3.2$ & $\begin{array}{c}\text { 2x/week-q } 2 \\
\text { weeks }\end{array}$ & $\begin{array}{l}\text { Range 1-117 } \\
\text { weeks (mean } \\
88 \text { weeks) }\end{array}$ & $10-12$ & $\begin{array}{l}\text { Peritonitis (1)Pyrexia (1) } \\
\text { Hypertension (1) } \\
\text { Gastroenteritis (3) } \\
\text { Convulsions (1) } \\
\text { Catheter site infection (2) } \\
\text { Device-related infection (1) }\end{array}$ \\
\hline
\end{tabular}

preterm infants $<48 \mathrm{~h}$ of age with a birth weight of $500-1,250 \mathrm{~g}$. Preterm infants treated with darbepoetin alfa also presented better neurocognitive outcomes at 18 to 22 months and at 3.5 to 4 years, compared to placebo treated neonates $(18,19)$. In that specific group, darbepoetin alpha was given at a starting dose of $10 \mu \mathrm{g} / \mathrm{kg}$ every week subcutaneously. A recent Cochrane review (20) evaluated effectiveness of DA in low birth weight newborns with the significative outcome on RBC transfusions and necrotising enterocolitis during neonatal period as well as neurodevelopment until the age of 2 .

More recently, darbepoetin alfa has also been used as a neuroprotective agent in conjunction with cooling therapy for hypoxic-ischemic encephalopathy in neonates. Baserga et al. (21) found darbepoetin alpha to be safe in critically ill neonates undergoing hypothermic therapy, at doses varying between 2 and $10 \mu \mathrm{g} / \mathrm{kg}$. Further studies are necessary to assess if darbepoetin contributes to improvement of neurological outcomes. Darbepoetin alfa has been used for many years in older pediatric cancer patients to treat chemotherapy-induced anemia, at a recommended dosage of $2.25 \mu \mathrm{g} / \mathrm{kg}$ weekly or $500 \mu \mathrm{g}$ every 3 weeks subcutaneously (22-24). Dosage of darbepoetin alpha seems to be similar in children with anemia secondary to CKD or to prematurity, but experience is sparse and target hemoglobin are different from other indication, making comparisons difficult. In our patients we observed a satisfactory response, without any documented adverse effects during a follow-up of 18-41 months.

Interestingly and as recently shown by Schaefer et al. (13), we found that patients younger than 1 year of age required a larger darbepoetin alfa dosage than older ones. In our observation the range of darbepoetin alfa dosage varied from 1.2 to $2.9 \mu \mathrm{g} / \mathrm{kg}$ per month, close to the dosage reported in Schaefer's study (1.7$3.2 \mu \mathrm{g} / \mathrm{kg}$ per month for subgroup of infants aged $<1$ year). This is higher than the recently recommended weekly dosage of $0.41 \mu \mathrm{g} / \mathrm{kg}$ (25-75th percentiles: $0.25-0.82 \mu \mathrm{g} / \mathrm{kg}$ ) in pediatric patients with CKD aged $1-18$ years (14).

The most frequently reported adverse effects of darbepoetin alfa are injection site pain, fever, headache, flu-like symptoms, hypertension, and thrombosis of vascular access, but their frequency compared favorably to another ESA (10-14). In children, subcutaneous injection of darbepoetin alfa has been reported by Schmitt et al. (25) to be more painful than those of epoetin-beta in a prospective, randomized, double-blind trial in 13 pediatric patients. In our study, we collected retrospectively all data concerning potential adverse events. Patient 1 and 2 were treated for hypertension, which started before darbepoetin alpha injections and was not worsen by the latter treatment. No injection site pain occurred in our patients, mainly because all of them received the darbepoetin intravenously. We observed no fever, seizure, headaches. However, it should be recognized that the short follow-up time and the very small number of patients preclude any firm conclusion regarding adverse effects of darbepoeitin alpha in this very young population with advanced CKD.

In conclusion, we report our results corroborate and extend the recent findings of Schaefer et al. (13). Prospective studies with larger sample size and longer follow-up should be conducted, to ensure darbepoetin alfa long lasting efficacy and the absence of severe or new adverse effects in young infants.

\section{AVAILABILITY OF DATA AND MATERIALS}

The data sets used for this article are available from the corresponding author upon request.

\section{CONSENT TO PUBLISH}

Parents of the three infants have given their consent to participate in this study and publish the results.

\section{ETHICS STATEMENT}

According to the Swiss ethics guidelines, the use of experimental therapy, done for a pure therapeutic goal (without a research goal) is based on the best judgment of the clinician for the benefit of a given patient and is being decided on a case by case basis. Our article is a retrospective analysis of 3 cases of experimental therapy used for the benefit of the patient only, and without a primary research goal. In such a condition, the Local Ethics Committee intervention is not necessary. 


\section{AUTHOR CONTRIBUTIONS}

AL-N collected and analyzed the data, wrote the manuscript as submitted and agrees to be accountable for all aspects of the

\section{REFERENCES}

1. Pickett JL, Theberge DC, Brown WS, Schweitzer SU, Nissenson AR. Normalizing hematocrit in dialysis patients improves brain function. Am J Kidney Dis. (1999) 33:1122-30. doi: 10.1016/S0272-6386(99)70150-2

2. Mitsnefes MM, Daniels SR, Schwartz SM, Meyer RA, Khoury P, Strife CF. Severe left ventricular hypertrophy in pediatric dialysis: prevalence and predictors. Pediatr Nephrol. (2000) 14:898-902. doi: 10.1007/s004670000303

3. Chavers BM, Herzog CA. The spectrum of cardiovascular disease in children with predialysis chronic kidney disease. Adv Chronic Kidney Dis. (2004) 11:319-27. doi: 10.1053/j.arrt.2004.04.002

4. Jungers P, Choukroun G, Oualim Z, Robino C, Nguyen AT, Man NK. Beneficial influence of recombinant human erythropoietin therapy on the rate of progression of chronic renal failure in predialysis patients. Nephrol Dial Transplant. (2001) 16:307-12. doi: 10.1093/ndt/16.2.307

5. Amaral S, Hwang W, Fivush B, Frankenfield D, Furth S. Association of mortality and hospitalization with achievement of adult hemoglobin targets in adolescents maintained on hemodialysis. J Am Soc Nephrol. (2006) 17:287885. doi: 10.1681/ASN.2005111215

6. Staples AO, Wong CS, Smith JM, Gipson DS, Filler G, Warady BA, et al. Anemia and risk of hospitalization in pediatric chronic kidney disease. Clin J Am Soc Nephrol. (2009) 4:48-56. doi: 10.2215/CJN.05301107

7. KDOQI clinical practice guideline and clinical practice recommendations for anemia in chronic kidney disease: 2007 Update of hemoglobin target. Am J Kidney Dis. (2007) 50:471-530. doi: 10.1053/j.ajkd.2007.06.008

8. KDIGO clinical practice guideline for anemia in chronic kidney disease. Kidney Int Suppl. (2012) 2:283-9. doi: 10.1038/kisup.2012.41

9. Boehm M, Riesenhuber A, Winkelmayer WC, Arbeiter K, Mueller T, Aufricht C. Early erythropoietin therapy is associated with improved growth in children with chronic kidney disease. Pediatr Nephrol. (2007) 22:1189-93. doi: 10.1007/s00467-007-0472-8

10. Lerner G, Kale AS, Warady BA, Jabs K, Bunchman TE, Heatherington A, et al. Pharmacokinetics of darbepoetin alfa in pediatric patients with chronic kidney disease. Pediatr Nephrol. (2002) 17:933-7. doi: 10.1007/s00467-002-0932-0

11. Rijk Y, Raaijmakers R, Van de Kar N, Schröder C. Intraperitoneal treatment with darbepoetin for children on peritoneal dialysis Pediatr Nephrol. (2007) 22:436-40. doi: 10.1007/s00467-006-0343-8

12. Durkan AM, Keating Laura E, Vigneux A, Geary Denis F. The use of darbepoetin in infants with chronic renal impairment Pediatr Nephrol. (2006) 21:694-7. doi: 10.1007/s00467-006-0067-9

13. Schaefer F, Hoppe B, Jungraithmayr T, Klaus G, Pape L, Farouk M, et al. Safety and usage of darbepoetin alfa in children with chronic kidney disease: prospective registry study. Pediatr Nephrol. (2016) 31:443-53. doi: 10.1007/s00467-015-3225-0

14. Warady BA, Arar MY, Lerner G, Nakanishi AM, Stehman-Breen C. Darbepoetin alfa for the treatment of anemia in pediatric patients with chronic kidney disease. Pediatr Nephrol. (2006) 21:1144-52. doi: 10.1007/s00467-006-0071-0

15. Geary D, Keating L, Vigneux A, Stephens D, Hébert D, Harvey E. Darbepoetin alfa (Aranesp ${ }^{\mathrm{TM}}$ ) in children with chronic renal failure Kidney Int. (2005) 68:1759-65. doi: 10.1111/j.1523-1755.2005.00592.x work. FC and MP participated in collecting the data and critically reviewed the manuscript. HC collected and analyzed the data, wrote the manuscript and critically reviewed the manuscript. All authors approved the final version of the manuscript.

16. De Palo T, Giordano M, Palumbo F, Bellantuono R, Messina G, Colella V, et al. Clinical experience with darbepoietin alfa (NESP) in children undergoing dialysis. Pediatr Nephrol. (2004) 19:337-40. doi: 10.1007/s00467-003-1364-1

17. Ohls RK, Christensen RD, Kamath-Rayne BD, Rosenberg A, Wiedmeier SE, Roohi M, et al. A randomized, masked, placebo-controlled study of darbepoetin alfa in preterm infants. Pediatrics (2013) 132:e119-27. doi: 10.1542/peds.2013-0143

18. Ohls RK, Kamath-Rayne BD, Christensen RD, Wiedmeier SE, Rosenberg A, Fuller J, et al. Cognitive outcomes of preterm infants randomized to darbepoetin, erythropoietin, or placebo. Pediatrics (2014) 133:1023-30. doi: 10.1542/peds.2013-4307

19. Ohls RK, Cannon DC, Phillips J, Caprihan A, Patel S, Winter S, et al. Preschool assessment of preterm infants treated with darbepoetin and erythropoietin. Pediatrics (2016) 137:e20153859. doi: 10.1542/peds.2015-3859

20. Ohlsson A, Aher SM. Early erythropoiesis stimulating agents in preterm or low birth weight infants. Cochrane Database Syst Rev. (2017) 11:CD004863. doi: 10.1002/14651858.CD004863.pub5

21. Baserga MC, Beachy JC, Roberts JK, Ward RM, DiGeronimo RJ, Walsh WF, et al. Darbepoetin administration to neonates undergoing cooling for encephalopathy: a safety and pharmacokinetic trial. Pediatr Res. (2015) 78:315-22. doi: 10.1038/pr.2015.101

22. Blumer J, Berg S, Adamson PC, Loew T, Rossi G, Hastings C. Pharmacokinetic evaluation of darbepoetin alfa for the treatment of pediatric patients with chemotherapy induced anemia Pediatr Blood Cancer (2007) 49:687-93. doi: $10.1002 /$ pbc. 21079

23. Marec-Berard P, Chastagner P, Kassab-Chahmi D, Casadevall N, Marchal C, Misset J, et al. 2007 Standards, Options, and Recommendations: use of erythropoiesis-stimulating agents (ESA: epoetin alfa, epoetin beta, and darbepoetin) for the management of anemia in children with cancer. Pediatr Blood Cancer (2009) 53:7-12. doi: 10.1002/pbc. 21953

24. Zachariah M, Elshinawy M, Alrawas A, Bashir W, Elbeshlawi I, Tony S, et al, Single dose darbepoetin alfa is useful in reducing red cell transfusions in leukemic children receiving chemotherapy. Pediatr Hematol Oncol. (2014) 31:442-7. doi: 10.3109/08880018.2013.824527

25. Schmitt CP, Nau B, Brummer C, Rosenkranz J, Schaefer F. Increased injection pain with darbepoetin-alfa compared to epoetin-beta in paediatric dialysis patients. Nephrol Dial Transplant. (2006) 21:3520-4. doi: 10.1093/ndt/ gfl479

Conflict of Interest Statement: The authors declare that the research was conducted in the absence of any commercial or financial relationships that could be construed as a potential conflict of interest.

Copyright (C) 2018 Libudzic-Nowak, Cachat, Pascual and Chehade. This is an openaccess article distributed under the terms of the Creative Commons Attribution License (CC BY). The use, distribution or reproduction in other forums is permitted, provided the original author(s) and the copyright owner(s) are credited and that the original publication in this journal is cited, in accordance with accepted academic practice. No use, distribution or reproduction is permitted which does not comply with these terms. 